\title{
RACING PERFORMANCE RECOVERY OF A HORSE SUBMITTED TO ARYTENOIDECTOMY AND VENTRICULECTOMY FOR THE TREATMENT OF RIGHT LARYNGEAL HEMIPLEGIA NOT RESPONSIVE TO LARYNGOPLASTY - CASE REPORT
}

\author{
RETORNO À FUNÇÃO ESPORTIVA DE UM CAVALO SUBMETIDO À ARITENOIDECTOMIA E \\ VENTRICULECTOMIA PARA TRATAMENTO DE HEMIPLEGIA LARÍNGEA DIREITA NÃO \\ RESPONSIVA À ARITENOIDEPEXIA - RELATO DE CASO
}

A. M. BOSI ${ }^{1}$; O. SPADETO Jr. ${ }^{2}$; C. S. COELHO ${ }^{3} *$;. E. S. ALVES ${ }^{4}$

\begin{abstract}
SUMMARY
An 11 year-old Quarter Horse stallion, a participant of three barrel racings, was admitted for clinical evaluation because of inspiratory noises. The wheezing had begun 20 days earlier and the animal was treated with meloxican, dexamethasone and sodium ceftiofur. Respiratory endoscopy revealed grade IV right and grade II left laryngeal hemiplegia, arytenoid chondritis and rostral displacement of the cricopharyngeal arch. Eight days after endoscopy, the horse received an emergency tracheostomy because its respiratory problems worsened. The animal was admitted at the Hospital Veterinário of PUC - Betim, MG, Brazil, where it was submitted to a right laryngoplasty. Five days later, clinical signs remained the same and endoscopy revealed that the right arytenoid asymmetry was not totally treated. In a new surgical procedure, the laryngoplasty was undone and the horse was submitted to a right arytenoidectomy associated with ventriculectomy. One week later, endoscopy revealed a partial obstruction of the laryngeal lumen caused by exuberant granulation tissue, which was controlled by topical application of dexamethasone twice a day. The animal remained hospitalized for 88 days. Five months after the last surgical procedure, the horse returned to competitions with an athletic performance similar to its previous one. It was possible to conclude that the association of arytenoidectomy and ventriculectomy was efficient for the treatment of right laryngeal hemiplegia after laryngoplasty failure and the associated techniques also lead to the return of athletic functionality.
\end{abstract}

KEY-WORDS: Arytenoidectomy. Equine. Right laryngeal hemiplegia.

\section{RESUMO}

Um equino macho, de 11 anos, da raça Quarto de Milha, utilizado em competições de três tambores, apresentando ruídos inspiratórios foi encaminhado para atendimento. O histórico revelou que os ruídos iniciaram 20 dias antes e que o animal havia sido medicado com meloxican, dexametasona e ceftiofur sódico. Por endoscopia respiratória, diagnosticou-se hemiplegia laríngea direita (grau IV) e esquerda (grau II), condrite das aritenóides e deslocamento rostral do arco palato faríngeo. Oito dias após endoscopia, o equino apresentou dificuldade respiratória, sendo necessária a realização de traqueostomia de emergência. O animal foi encaminhado para o Hospital Veterinário da PUC - Betim, MG, onde foi submetido à cricoaritenoidepexia direita. Cinco dias após constatou-se persistência dos sinais clínicos e por endoscopia observou-se que a assimetria da aritenóide direita não havia sido totalmente corrigida. Em novo procedimento cirúrgico, a aritenoidepexia foi desfeita e realizou-se aritenoidectomia direita associada à ventriculectomia. Uma semana depois, por endoscopia, observou-se obstrução parcial do lúmen da laringe por tecido de granulação exuberante, que foi controlado por tratamento tópico com dexametasona duas vezes ao dia. O equino ficou hospitalizado 88 dias. Cinco meses após a última cirurgia o animal retornou às competições com desempenho semelhante ao que apresentava anteriormente. Foi possível concluir que a associação de aritenoidectomia e ventriculectomia foi eficiente para o tratamento de hemiplegia laríngea direita após insucesso da aritenoidepexia, com retorno do animal a sua função atlética.

PALAVRAS-CHAVE: Aritenoidectomia. Equino. Hemiplegia laríngea direita.

\footnotetext{
${ }^{1}$ Faculdade de Medicina Veterinária - Universidade Vila Velha (UVV-ES).

${ }^{2}$ Faculdade de Medicina Veterinária - Universidade Vila Velha (UVV-ES).

${ }^{3}$ Faculdade de Medicina Veterinária e Programa de Mestrado em Ciência Animal - Universidade Vila Velha (UVV-ES). Rua Comissário José Dantas de Melo, 21. CEP: 29102-770. Vila Velha - ES. Corresponding author: clarisse.coelho@uvv.br.

${ }^{4}$ Faculdade de Veterinária - UFMG.
} 
Respiratory diseases are the second cause of exercise intolerance, being the illnesses of the anterior respiratory tract common in all breeds of high performance horses (LAGUNA, 2006). Among these diseases, laryngeal hemiplegia (HL) is highlighted (BEARD, 1996). It is distributed worldwide, and affects animals of various breeds and both sexes (BEARD \& HAYNES, 1993). Brown et al. (2003) reported that among the diseases of the anterior tract, HL has an incidence between $2.6 \%$ and $11 \%$ in sport horses while Brakenhoff et al. (2006) have suggested that between $40 \%$ and $95 \%$ of large breeds of horses have some degree of asymmetry of the arytenoids. According to Beard \& Haynes (1993), it is more common in male Thoroughbred horses.

In its classic form, HL is described as spontaneous disease resulting from primary degeneration of the recurrent laryngeal nerve for various reasons, like injuries by injection of irritants, guttural pouch inflammation and abscesses, viral and bacterial infections, among others (FULTON et al. 1991; BEARD \& HAYNES, 1993; THOMASSIAN, 2005). Generally, the left side is the most affected, resulting in atrophy of the dorsal cricoarytenoid muscle in about $95 \%$ of the cases observed, leading to changes in adduction/abduction of the arytenoid cartilage, generating inspiratory noise and characteristic exercise intolerance (FULTON et al., 1991; D'UTRA VAZ et al., 1998; D'UTRA VAZ et al., 2000; THOMASSIAN, 2005). According to Laguna (2006), the sounds are characteristically acute, vibrating like a whistle and produced only during inspiration. So, they are popularly known as wheeze and different from those produced by other laryngeal obstructions ("Husky/snores"), caused by dorsal displacement of the soft palate and epiglottis entrapment, in which higher vibration sounds are produced and are present during both inspiration and expiration (LAGUNA, 2006).

The HL was classified into four grades by Hackett et al. (1991). Animals with more severe degrees of the disease may exhibit respiratory collapse due to the stress caused by ariteno-epiglottic folds together with paralysis of the arytenoid and vocal cord corresponding, due to the high tension inspiration (THOMASSIAN, 2005). Thomassian (2005) explained that the signs of severe respiratory distress may be progressive or settle acutely, generating signs of hypoxia, hypercapnia, and metabolic acidosis, particularly if there is a rare bilateral involvement.

D'Utra-Vaz et al. (2000) and Thomassian (2005) stated that digital palpation of the dorsal cricoarytenoid muscle can diagnose HL, because there is atrophy in cases of advanced degree hemiplegia. The examination of the horse during exercise to observe the audible wheeze even from a distance should be done with caution, because the intensity of paralysis and exercise may cause hypoventilation, cyanosis, acidosis, and even respiratory failure. As the horse recovers its normal respiratory parameters, the wheezing and discomfort to inspiration tend to decrease gradually (THOMASSIAN, 2005). According to D'Utra-Vaz et al. (1998) and Stick \& Holcombe (1998), the definitive diagnosis is made by endoscopic examination of the larynx, where it is possible to observe that the affected cartilage is positioned paramedian to the rhyme of the glottis. Laguna (2006) added that the endoscopic examination performed with the horse moving on the treadmill allows observation of dynamic changes that occur only during submaximal or maximal exercise and are not apparent when standing still.

Treatment is surgical, using procedures such as laryngoplasty with or without ventriculectomy and, when HL is severe or associated with other complications, arytenoidectomy, and tracheostomy (FULTON et al., 1991, D'VAZ-UTRA et al., 1998).

Laryngoplasty is the most used technique and its main objective is to prevent the permanence of the arytenoid cartilage and chord in the adduction position during exercise, keeping the cartilage in the full abduction position and improving airflow (CAHILL \& GOULDEN, 1991; KRAUS et al., 2003). With the animal under general anesthesia in the lateral decubitus position and extended neck, a tension band is placed between the cricoid and arytenoid muscular process, so that the arytenoid abduction remains constant (BROWN et al., 2004). The tension band material used depends on the individual surgeon, but usually they are braided polyester threads, monofilament nylon, among others (VALDÉS, 2006). Possible complications include infection of the tension band, fistula, cartilage ossification, dysphagia, esophageal obstruction, food or water aspiration pneumonia, granulomatous intralaryngeal polyps, laryngospasm during exercise, laryngeal edema, chondrite and cough (HAWKINS et al., 1997). Rakesh et al. (2008) stated that the technique success rate in horses undergoing submaximal exercise is $90 \%$, but only $60 \%$ in race horses (maximal intensity exercise).

Ventriculectomy is performed with the animal in the supine position under general anesthesia, immediately after the laryngoplasty (KRAUS et al., 2003), to reduce the noise associated with the disease (KIDD \& SLONE, 2002). It consists of removing the ventricle lining and maybe concomitantly removing the vocal cords, as well (cordectomy). Complications are similar to those described for laryngoplasty (D'UTRA VAZ et al., 1998).

The arytenoidectomy was the surgical treatment of choice for HL; however, most animals had postoperative dysphagia and aspiration pneumonia (BEECH, 1991). In recent years, it has been used in cases of failed laryngoplasty or in cases of arytenoid chondritis, where it is the only possible treatment (BEECHER, 1991; D'UTRA Vaz et al., 2000). According to D'Utra-Vaz et al. (2005), arytenoidectomy is accomplished through a laryngectomy, with the animal in dorsal recumbency and under general anesthesia. There are three arytenoidectomy techniques: total (removal of the entire arytenoid cartilage including the muscular and corniculate processes), partial (removal of the arytenoid cartilage and corniculate process) and subtotal (removal of the arytenoid cartilage, preserving the corniculate and muscular processes) (D'UTRA 
VAZ et al., 1998). Most of these horses return to sports activities, but with reduced performance. Animals with severe bilateral disease are less likely to return to athletic function. Major complications may include dyspnea and dysphagia. The use of tracheal tube and anti-inflammatory drugs allows the animal to breathe better while the healing process takes place, which should be monitored with follow-up endoscopies.

The prognosis, with respect to regaining athletic performance, for horses that are subjected to any of the techniques described should be reserved. The diseases caused by neuromuscular disorders are important since these have reserved prognosis in equine sports (THOMASSIAN, 2005; SANTOS et al., 2007).

This paper describes the case of a horse diagnosed with right (grade IV) and left (grade II) HL, arytenoid chondritis and rostral displacement of the pharyngeal palate arch, which were surgically treated with associated arytenoidectomy and ventriculectomy.

An 11-year-old, male Quarter Horse, weighing $470 \mathrm{~kg}$, athlete of three barrel racings, was referred to veterinary medical care in an emergency. According to the owner, the animal had extreme difficulty in breathing accompanied by inspiratory noise, wheezing, that had started a week earlier. The last race the horse participated had happened 30 days earlier and since then the animal was not being worked. Upon initial physical examination, the animal had severe dyspnea and inspiratory noise, at rest, audible even from a distance. The oral mucosa showed mild cyanosis. The endoscopy diagnosed grade IV right and grade II left HL, with partial stenosis of the glottis rhyme, arytenoid chondritis and rostral displacement of the pharyngeal arch palate (Figure 1A). The veterinarian prescribed meloxicam (Maxican Gel®) $0.6 \mathrm{mg} / \mathrm{kg}$ once a day orally for 5 days; dexamethasone (Azium ${ }^{\circledR}$ ) $0.1 \mathrm{mg} / \mathrm{kg}$ once a day, IM, for three days; and, sodium ceftiofur (Cef Top®) $4.4 \mathrm{mg} / \mathrm{kg}$, once a day, IM, for 10 days. Eight days later, the dyspnea had worsened, which required emergency tracheostomy and the animal was referred to the Veterinary Hospital of the PUC in Betim, Minas Gerais. A new physical examination was performed using a rebreathing bag, a plastic bag over the nose to intensify the horse respiratory effort and hence the sound. The test showed intense wheezing and dyspnea. The wheezing could still be heard during a new evaluation performed after 10 minutes of physical activity. Subsequently, a new endoscopy performed with the horse at rest, using the "slap test", confirmed the previous diagnosis. The preoperative treatment prescribed consisted of: nostrils decongestant (inhaled with steaming hot water containing $15 \mathrm{ml} / \mathrm{l}$ of water to Penetro ${ }^{\circledR}$, Eucalyptol $33 \mathrm{mg} / \mathrm{ml}$, monohydrate terpene $22 \mathrm{mg} / \mathrm{ml}$ and Menthol $22 \mathrm{mg} / \mathrm{ml}$ ), dexamethasone (Azium $\left.{ }^{\circledR}\right) 0.05 \mathrm{mg} / \mathrm{kg}$, IM, levamizole (Ripercol®) $2.5 \mathrm{mg} / \mathrm{kg}$, penicillin (reinforced Pentabiotic $\left.{ }^{\circledR}\right) \quad 22,000 \quad \mathrm{UI} / \mathrm{kg}$ and dressing of the tracheostomy area three times a day. A week later, after a 12-hour fasting, the horse was subjected to right laryngoplasty.

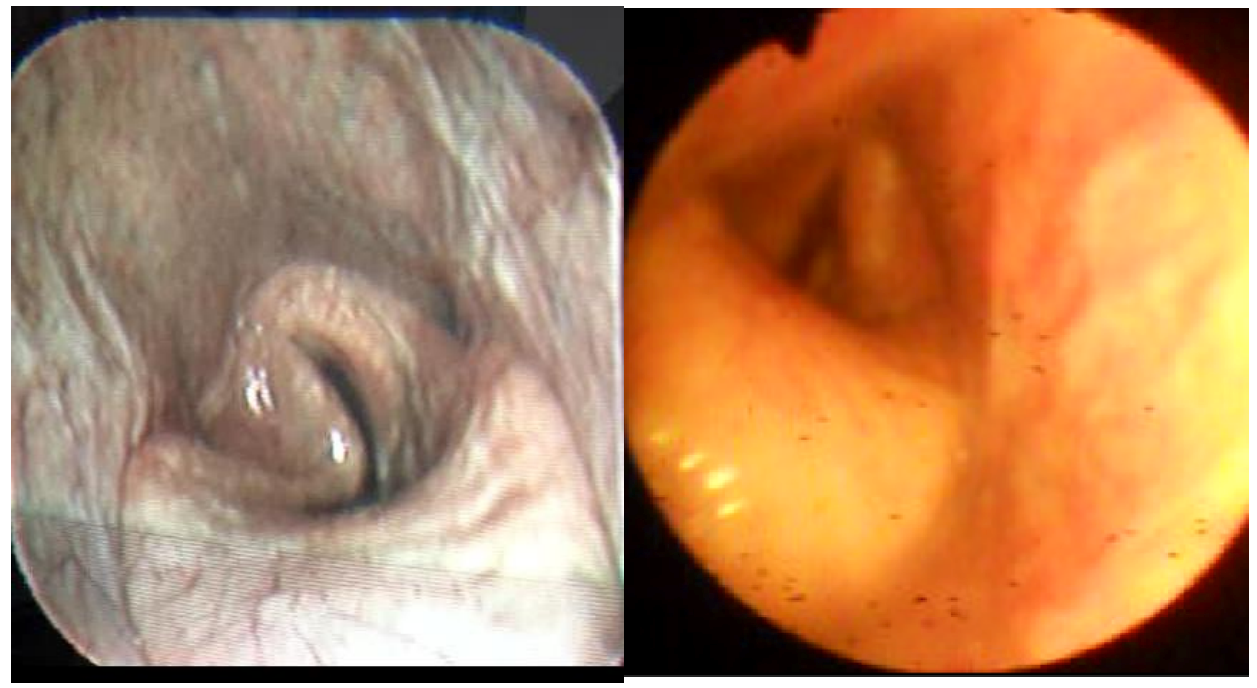

Figure 1 - (A) Photography obtained during bronchoscopy (A) at the time, it was diagnosed grade IV right and grade II left laryngeal hemiplegia with partial stenosis of the rhyme of the glottis, arytenoid chondritis and rostral displacement of the pharyngeal arch palate, (B) five months after arytenoidectomy, when the horse resumed full physical activities.

Under general anesthesia, positioned on left lateral decubitus with extended head and neck, the horse received a tension band between the cricoid and arytenoid muscular process to abduct it. A ventral 8-cm incision parallel to the linguofacial vein, extending up to the cricotracheal space was performed to access the area. Dissection was performed between the linguofacial vein and the omohyoid muscle up to the caudal cricoid. The oropharyngeal and cricopharyngeal muscles were separated to allow access to the arytenoid muscular process. The tension band wiring used Surlene 2 (blue polypropylene), needled with $3 / 8$ circle 
trocar needle. The needle was carefully inserted under the caudal border of the cricoid, preventing its entry into the lumen of the larynx. The wire was passed under the cricopharyngeal muscle and through the right arytenoid muscle process, followed by the adjustment aiming at abduction and the surgical knots for fixation. The adjustment was guided by intraoperative endoscopy. During the adjustment of the tension band, ankylosis of the cricoarytenoid joint was observed. At this point, the knot was undone, and curettage of the joint was performed using a curette Bruns with shell 000. Next, the knot was redone and the tension band adjusted without the expected effect. Subsequently, synthesis of the subcutaneous plans and the skin was performed, maintaining a Penrouse no. 2 drain.

After the surgical procedure, an asymmetry of the right arytenoid was observed with the endoscope. Postoperatively the horse still had the tracheal tube, which was taken once a day to observe the animal's breath. The wheezing showed that that the asymmetry of the right arytenoid cartilage had not been fully corrected. Furthermore, the chondrite had worsened. Therefore, it was decided for a re-intervention to remove the tension band, followed by laryngectomy, total arytenoidectomy and right ventriculectomy. The laryngectomy of $10 \mathrm{~cm}$ was performed under general anesthesia with the horse in the supine position. Subsequently, the total right arytenoidectomy (removal of the entire arytenoid cartilage including the muscular and corniculate processes) was performed using a Weitlaner retractor of $20 \mathrm{~cm}$, scalpel handle 3 long with 11 blade, Baliu scissors of $20 \mathrm{~cm}$ and Koucher and Allis calipers of $20 \mathrm{~cm}$. There was particular difficulty due to the advanced chondrite, characterized by irregular hardened cartilage tissue, with foci of ossification and non-apparent interfaces with the surrounding structures and mucosa. Ventriculectomy was performed concurrently with right arytenoidectomy (Figure 1B). Larynx suture was not performed aiming at healing by secondary intention. The horse recovered from the anesthesia and was transferred to the bay while kept breathing through tracheotomy.

The postoperative treatment included local instillation of dexamethasone using a probe that reached the region of the surgical wound; gentamicin $6.6 \mathrm{mg} / \mathrm{kg}$; penicillin 22,000 UI/kg; flunixin meglumine $1.1 \mathrm{mg} / \mathrm{kg}$, once a day for 4 days; tracheostomy cleaning with saline solution three times a day.

During the postoperative period, the animal presented dyspnea when tested by occlusion of the tracheostomy. This was due to the development of exuberant scar tissue in the region where the arytenoidectomy had been performed; the horse had labored breathing and wheezing. The tracheostomy was maintained until the exuberant granulation was controlled with topical therapy. During the postoperative period, the horse responded satisfactorily when the tracheal tube was removed gradually, for periods at time, so that the animal could breathe through the nostrils and rehabilitate the healing tissue in the larynx.
About three months after the first vet care, the animal was discharged without unusual respiratory signs. Five months after surgery, the animal returned to full athletic activity without abnormal respiratory signs. After two years of surgery, the animal had no signs of breathing difficulty or wheezing and continues in full athletic activity.

This report describes the right HL case of an 11year-old Quarter Horse that practiced three barrel racing. According to Beard \& Haynes (1993), HL is more common in Thoroughbred males. Unlike the case described, Harrison et al. (1992) reported that the disease is juvenile, with $43 \%$ of cases occurring in horses aged two years or younger, $75 \%$ in horses younger than three years and $90 \%$ before the age of five. Evans (2001) reported that the early and rigorous training that Thoroughbred foals undergo, predispose them to HL

The occurrence of $\mathrm{HL}$ in the right side is unusual (FULTON et al., 1991; HAWKINS et al., 1997; KRAUS et al., 2003). According to Laguna (2006), a study performed at the Jockey Club of São Paulo showed that the left side was affected in $91.50 \%$ of cases (323 horses); the right side in $7.37 \%$ (26 horses); and, bilateral involvement, similar to the case described in this study was diagnosed in $1.13 \%$ of the horses studied. There are few reports in the literature (SPECHT et al., 1989; TULLENERS et al., 1996). Specht et al. (1989) considered as etiologic possibilities, extravascular injections and injuries in the region, and the guttural pouch mycosis, neoplasia and cervical lymphadenopathy, similar to the causes mentioned for the HL affecting the left side (FULTON et al., 1991; BEARD \& HAYNES, 1993; THOMASSIAN, 2005). Moreover, Dixon (2005) reported that a large proportion of horses with laryngeal dysfunction of the right side show a mechanical malfunction of the larynx, especially due to the equine cricopharyngeal-laryngeal dysplasia syndrome. Tulleners et al. (1996) cited concomitant problems such as pulmonary infections and Horner syndrome, some cases of HL in the right side.

Clinical signs observed in this report, such as severe dyspnea, wheezing and cyanotic oral mucosa, even at rest, are compatible with severe and acute case, similar to several reports in the literature of the left HL (FULTON et al., 1991; D'VAZ-UTRA et al., 1998; D'UTRA VAZ et al., 2000; THOMASSIAN, 2005).

Whatever the cause of recurrent right laryngeal nerve injury, the treatment is the same as that performed for left HL, in order to abduct the arytenoid cartilage affected, to increase the lumen of the larynx and/or prevent its dynamic collapse during physical exercise (DIXON, 2005). Of the various surgical maneuvers described in the literature to treat these diseases, arytenoidectomy procedure is indicated in cases of HL, especially when laryngoplasty fails (LUMSDEN et al. 1994). In general, the laryngoplasty has been effective in the treatment of HL since it reduces wheezing and improves athletic performance (FULTON et al., 1991; LAGUNA, 2006). Hawkins et al. (1997) reported that $77 \%$ of horses with left HL undergoing laryngoplasty, with or without associated 
Ventriculectomy, returned to racing at least once after surgery and $69 \%$ of patients improved their athletic performance. Kraus et al. (2003) documented recovery rates for post-laryngoplasty associated with ventriculectomy or ventriculecordectomy of $82 \%$ in traction horses and $69 \%$ in racehorses, justifying this difference on the lower strenuous demand to which traction horses are subject compared to racehorses. However, as most surgeons are familiar with the left side technique, the right side surgery might not be so successful and is subjected to possible failures, such as excessive abduction of the affected cartilage, and therefore a post-operative dysphagia (DIXON, 2005).

A possible explanation for the failure of laryngoplasty in the described case is the concomitant ankylosis of the right cricoarytenoid that, even after curettage, did not allow complete abduction of the arytenoid by the tension band. The associated arytenoidectomy and ventriculectomy was the alternative treatment adopted due to both lack of response of the laryngoplasty and concomitant presence of arytenoid chondritis. According to Davenport-Goodall \& Parente (2003), chondropathy arytenoid, especially in the early stages, may be confused with HL when the test is performed in the horse at rest. Additionally, the authors mentioned that in cases of chondropathy, the pharyngeal arch palate is prominent, similar to that found in the equine endoscopy of the present report. Inversely to Beech (1991), the chondrite diagnosed in the equine was observed in both arytenoids and their presence would be enough to consequently obstruct airflow. Thus, the only therapy indication is arytenoidectomy (BEECH, 1991; LUMSDEN et al., 1994; D'UTRA VAZ et al., 2000).

The second surgical procedure (arytenoidectomy associated with ventriculectomy) had satisfactory outcome. Although this technique presents complications such as coughing, dysphagia and aspiration of food contents (FULTON et al., 1991; HAWKINS et al., 1997), the animal of this report has not developed such complications while the surgery corrected the obstruction of the rhyme glottis and restored the passage of air, which allowed the return to athletic activity in five months with regular performance. There are no reports of recovery rates of post-arytenoidectomy to treat right HL. Specht et al. (1991) documented the spontaneous recovery of a horse with right HL undergoing laryngoplasty with ventriculectomy. The comparison with the laryngoplasty techniques associated with cordectomy and aritenoidectomy performed by Radcliffe et al. (2006) in six horses with induced left HL, the authors found that both procedures restored ventilation to almost normal in submaximal exercise, but when exercise is performed at maximal level, the laryngoplasty proved slightly more efficient. Laguna (2006) concluded that the subtotal arytenoidectomy performed in a small number of horses was ineffective for maintaining the postoperative performance of the animals. The author warned that it should be used only as a last resort due to unsatisfactory results and the high cost-benefit ratio.
Kidd \& Stone (2002) evaluated the cordectomy contribution to the success rate and incidence of postoperative wheezing and found that cordectomy was important in reducing wheezing, satisfying a common complaint of owners, but without impacting performance on return to physical activity. Although the horse of this case report was not subjected to this technique, the wheezing disappeared after the procedure. Before, the wheezing could be heard with the animal at rest. In addition, the horse also returned to athletic activity, suggesting that ventriculectomy can significantly reduce wheezing when associated with other techniques such as laryngoplasty (DIXON, 2005).

Tracheostomy is necessary due to the extreme difficulty in breathing caused by the most severe HL and postoperatively, due to the swelling in the pharynx-larynx region (D'UTRA VAZ et al., 1998). This procedure was adopted on an emergency basis in this case for the reasons described above. According to Dixon (2005), tracheostomy has been indicated permanently in horses with anterior airways obstruction, but its use has become intermittent, or only for a short period, usually the immediate postoperative period, due to its rejection by the owners for aesthetical reasons.

Analyzing the literature, the presentation and clinical evolution of the disease, associated with endoscopic respiratory findings, one could suggest that the horse had a main obstruction caused by the right arytenoid, with minor injuries on the left side of the larynx, a fact rarely described. Effective treatment was the most invasive, opting for total right arytenoidectomy associated with right ventriculectomy, which was successful and allowed the animal to return to its sports activities.

Finally, the individuality factor inherent to the patient should be considered as an influence on the outcome of the second surgical procedure.

\section{REFERENCES}

BEARD, W. L.; HAYNES, H.M. Risk factors for laryngeal hemiplegia in the horse. Preventive Veterinary MedicaI, v.17, p.57-63, 1993.

BEARD, W. Upper respiratory causes of exercise intolerance. Veterinary Clinics of North America Equine Practice, v.12, n.3, p.435-455, 1996.

BEECH, J. Miscellaneous lung and pleural injuries. In: BEECH, J. Equine respiratory disorders. Philadelphia: Lea \& Febiger, 1991. p.215-222.

BRAKENHOFF, J. E.; HOLCOMBE, S. J.; SMITH, H. K.; NICKELS, F. A.; CARN, J. P. Prevalence of Laryngeal Diseases in large population of competition draft horses. In: 52th ANNUAL CONVENTION OF THE AMERICAN ASSOCIATION OF EQUINE PRACTITIONERS - AAEP, 2006, San Antonio. Anais eletrônicos...Lexington: International Veterinary 
Information Service, 2006. Disponível em: www.ivis.org. Acesso em: 30/03/12.

BROWN, J. A.; DERKSEN, F. J.; STICK, J. A.; HARTMANN, W. M.; ROBINSON, N. E. Ventriculocordectomy reduces respiratory noise in horse with laryngeal hemiplegia. Equine Veterinary Journal, v.35, n.6, p.570-574, 2003.

BROWN, J. A.; DERKSEN, F. J.; STICK, J. A.; HARTMANN, W. M.; ROBINSON, N. E. Effect of laringoplasty on respiratory noise reduction in horses with laryngeal hemiplegia. Equine Veterinary Journal, v.36, n.5, p.420-425, 2004.

CAHILL, J.I.; GOULDEN, B.E. Disease of the larynx. In: COLAHAN, P. T.; MAYHEW, I.G.; MERRITT, A.M.; MOORE, J.N. Equine medicine and surgery. 4. ed. Goleta: American Veterinary Publications, 1991. p.412-21.

DAVENPORT-GOODALL, C. L. M.; PARENTE, E. J. Disorders of the larynx . Veterinary clinics of North America. Small Animal Practice, v.19, n.1, p.169-187, 2003.

DIXON, P. M. Treatment of right recurrent laryngeal neuropathy (RLN): Where are we? In: THIRD WORLD EQUINE AIRWAYS SYMPOSIUM, Ithaca, 2005. Lexington: International Veterinary Information Service, 2005. Disponível em: www.ivis.org. Acesso em: $30 / 03 / 12$.

D' UTRA VAZ, B. B.; THOMASSIAN, A.; HUSSINI, C. A.; NICOLETTI, J. L. M.; RASMUSSEN, R. Hemiplegia Laríngea e condrite da aritenóide em equinos. Ciência Rural, v.28, n.2, p.333-340, 1998.

D' UTRA VAZ, B. B.; THOMASSIAN, A.; HUSSINI, C. A.; NICOLETTI, J. L. M.; ALVES, A. L. G.; ZANELLA, L. F.; TEIXEIRA NETO, F. J. Aritenoidectomia subtotal com e sem remoção da mucosa laríngea de equinos submetidos a neurotomia do nervo laríngeo recorrente. Revista de Educação Continuada do CRMV-SP, v.3, n.3, p.44-56, 2000.

D' UTRA VAZ, B. B.; THOMASSIAN, A.; HUSSINI, C. A.; NICOLETTI, J. L. M.; ALVES, A. L. G.; FIGUEIREDO, L. M. A. Aspectos histológicos da laringe de equinos submetidos à aritenoidectomia subtotal com e sem remoção do revestimento mucoso. Veterinária Notícias, v.11, n.2, p.23-29, 2005.

EVANS, D. Training and wastage in young australian Thoroughbreds. In: CONGRESSO INTERNACIONAL DE MEDICINA ESPORTIVA EQUINA, 2001, Botucatu, Brasil. Anais... Botucatu: FMVZ, 2001. p.35-39.

FULTON, I. C.; DERKSEN F. J.; STICK, J. A.; ROBINSON, N. E.; WALSHAW, R. Treatment of left laryngeal hemiplegia in Standardbreds using a nerve muscle graft. American Journal of Veterinary Research, v.52, p.1461-1467, 1991.

HACKETT, R. P.; DUCHARME, N. G.; FUBINI, S. L.; ERB, H. N. The reliability of endoscopic examination in assessement of arytenoid cartilage movement in horses. Part I: subjective and objective laryngeal evaluation. Veterinary Surgery, v.20, n.3, p.174-179, 1991.

HARRISON, G. D.; DUNCAN, I. D.; CLAYTON, W. K. Determination of the early outset of equine recurrent laryngeal neuropathy I: muscle pathology. Acta Neuropathologica, v.84, n.44, p.307-315, 1992.

HAWKINS, J. F.; TULLENERS, E. P.; ROSS, M. W.; EVANS, L. H.; RAKER, C. H. W. Laryngoplasty with or without ventriculectomy for treatment of left laryngeal hemiplegia in 230 race horses. Veterinary Surgery, v.26, n.6, p.484-491, 1997.

KIDD, J. A.; SLONE, D. E. Treatment of laryngeal hemiplegia in horses by prosthetic laryngoplasty, ventriculectomy and vocal cordectomy. Veterinary Record, v.150, n.15, p.481-484, 2002.

KRAUS, B. M.; PARENTE, E. J.; TULLENERS, E. P. Laringoplasty with ventriculectomy or ventriculocordectomy in 104 draft horses (1992-200). Veterinary Surgery, v.32, n.6, p.530-538, 2003.

LAGUNA, G. G. L. Estudo Analítico das endoscopias das vias aéreas de equinos PSI durante o período de 199302003 e avaliação dos resultados de procedimentos cirúrgicos laringeanos realizados no Jockey Club de São Paulo durante o período de 19982003. Botucatu: Universidade Estadual Paulista, 2006. 269p. Tese (Doutorado em Medicina Veterinária) Faculdade de Medicina Veterinária e Zootecnia, 2006.

LUMSDEN, J. M.; DERKSEN, F. J.; STICK, J. A.; ROBINSON, N. E.; NICKELS, F. A. Evaluation of partial arytenoidectomy as a treatment for equine laryngeal hemiplegia. Equine Veterinary Journal, v.26, n.2, p.125-129, 1994.

RADCLIFFE, C. H.; WOODIE, J. B.; HACKETT, R. P.; AINSWORTH, D. M.; ERB, H. N.; MITCHELL, L. M.; SODERHOLM, L. V.; DUCHARME, N. G. A comparison of laryngoplasty and modified partical arytenoidectomy as treatments for laryngeal hemiplegia in exercising horses. Veterinary Surgery, v.35, n.7, p.643-652, 2006.

RAKESH, V.; DUCHARME, N. G.; CHEETHAM, J.; DATTA, A. K.; PEASE, A. P. Implications of different degrees of arytenoid cartilage abduction on equine upper airway characteristics. Equine Veterinary Journal, v.40, n.7, p.629-635, 2008.

SANTOS, L. C. P.; MICHELOTTO-JÚNIOR, P. V.; KOZEMJAKIN, D. A. Achados endoscópico e citológico das vias respiratórias de potros puro sangue 
inglês em início de treinamento no Jóquei Clube do Paraná. Arquivos de Ciências Veterinárias e Zoologia da Unipar, v.10, n.1, p.9-13, 2007.

SPECHT, T. E.; PEYTON, L. C.; NIXON, A. J.; ROSE, R. J. Spontaneous recovery from idiopathic right laryngeal hemiplegia in a horse. Canadian Veterinary Journal, v.30, p.593-594, 1989.

STICK, J. A.; HOLCOMBE, S. J. What to expect following surgery of obstructive lesions of the upper respiratory tract. PROCEEDINGS OF THE $44^{\mathrm{TH}}$ AAEP ANNUAL CONVENTION, 1998, Baltimore. Anais eletrônicos... Lexington: International Veterinary Information Service, 1998. Disponível em: www.ivis.org. Acesso em: 30/03/12.

THOMASSIAN, A.; WATANABE, M. J,; ALVES, A. L. G.; HUSSINI, C. A.; NICOLETTI, J. L. M. Aplicação da videoendoscopia no diagnostico de alterações do trato respiratório anterior em cavalos atletas. Revista Brasileira de Medicina Veterinária Eqüina, v.1, n.2, p.28-32, 2005.

TULLENERS, E. P.; ROSS, M. W.; HAWKINS, J. Management of right sided laryngeal hemiplegia in horses: 28 cases (1987-1996). In: ANNUAL AMERICAN COLLEGE OF VETERINARY SURGEONS SYMPOSIUM, 1996, Chicago. Proceedings...p.21-25.

VALDÉS, M. A. Does ventriculectomy-cordectomy improve the result of laringoplasty? In: PROCEEDINGS OF THE $9^{\mathrm{TH}}$ WEVA, 2006, Marrakesh. Anais eletrônicos... Lexington: International Veterinary Information Service, 2006. Disponível em: www.ivis.org. Acesso em: 30/03/12.

FIGURA 